\title{
SEED GERMINATION IN SIX ANTICANCEROUS PLANTS OF BANGLADESH
}

\author{
NAHID SULTANA ${ }^{1}$, M. OLIUR RAHMAN* AND MD. ABUL HASSAN \\ Department of Botany, University of Dhaka, Dhaka 1000, Bangladesh \\ ${ }^{I}$ Department of Botany, Jagannath University, Dhaka-1100, Bangladesh
}

\begin{abstract}
Six medicinal plants, namely Boerhavia diffusa L., Calotropis procera (Ait.) R. Br., Jatropha gossypifolia L., Leonurus sibiricus L., Plumbago zeylanica L. and Ricinus communis L. of Bangladesh having anticancerous properties were investigated with a view to knowing their seed germination time, rate and pattern. The minimum days taken for seed germination in B. diffusa, C. procera, J. gossypifolia, L. sibiricus, $P$. zeylanica and $R$. communis were $70,9,24,75,11$ and 14 , respectively. The maximum time (130 days) required for germination was observed in Leonurus sibiricus. The highest germination rate (100\%) was observed in Plumbago zeylanica, while the lowest rate $(10 \%)$ was found in Ricinus communis. Epigeal type of germination was noted in all the species employed.
\end{abstract}

Key words: Medicinal plants, Seed germination, Anticancer, Epigeal, Dormancy

\section{Introduction}

Plants having therapeutic properties or exerting beneficial pharmacological effects on the animal body are referred to as medicinal plants (van Valkenburg and Bunyapraphatsara 2002). Plants (their parts and products), particularly those with medicinal properties, are always used as principal components or ingredients of various traditional medicines. Cancer or malignant neoplasm is a disease where a group of cells show uncontrolled growth, invasion, and metastasis. Many plant species are already being used to treat or prevent cancer (Greenwell and Rahman 2015). Hartwell (1982) reported that over 3,000 plant species worldwide have anticancer properties. In Bangladesh, 220 species are also reported to have anticancerous activities (Sultana 2017).

Medicinal plants including the species having anticancerous potential in Bangladesh are at risk and going to be threatened because of over-exploitation, habitat degradation and deforestation. Therefore, these medicinal plants need to be preserved, multiplied, and propagated through different means including seed germination. Medicinal plants, particularly the species having anticancerous potential need to be brought under cultivation and in order to fulfil this target it is necessary to investigate their seed germination pattern.

Seed germination of six anticancerous plants commonly available in Bangladesh, viz., Boerhavia diffusa, Calotropis procera, Jatropha gossypifolia, Leonurus sibiricus, Plumbago zeylanica and Ricinus communis were investigated. Apart from anticancerous

*Author for correspondence: < prof.oliurrahman@gmail.com/ oliur.bot@du.ac.bd>. 
properties these species are also administered for treating different ailments with potent bioactive compounds. Leaves and roots of Boerhavia diffusa are administered in jaundice, anaemia, inflammation, and as blood purifier. Various parts of this species contain bioactive compounds phytol, sitosterol, ursolic acid, boerhavine and rotenoids (Ghani 2003). Calotropis procera possesses antifungal properties, and the root bark is employed in dyspepsia and flatulence, while flowers are used in asthma (Yusuf et al. 2009). Root bark of $C$. procera possesses alkaloids, benzollineolone while flower contains cyaniding 3rhamnoglucoside (Rastogi and Mehrotra 1993). Jatropha gossypifolia leaves are applied for treatment of boils, carbuncles, eczema and itches (Ahmed et al. 2008). The bioactive compounds found in the leaves of J. gossypifolia include flavonoids, a saponin, tannin and triterpenes (Ghani 2003). Stems, leaves and flowers of Leonurus sibiricus contain stachydrine, leonurine and sibirine, and seeds encompass leonurinine (Yusuf et al. 2009). Nutlets of this species are used as emmenagogue, diuretic and vasodilator (Nunez and de Castro 1992). Roots of Plumbago zeylanica bear plumbagin and zeylinone, and fresh roots are ground and used in the treatment of arthritis (Rastogi and Mehrotra 1993, Singh and Ali 1998). Ricinus communis seeds principally contain alkaloid ricinine and are administered for treating joint pains, and constipation (Yusuf et al. 2009).

Seed germination resulted from metabolic activity and growth of an embryo, ensuing in the break of the seed coat and emergence of the young plant. Germination occupies complex biochemical, physiological and morphological changes within the seed and depends upon seed viability, breaking of dormancy and suitable environmental conditions (Sadhu 1989). Several efforts have been made on seed germination and seedling emergence of different species including medicinal plants (Baskin et al. 1993, Hassan and Fardous 2003, Chauhan and Johnson 2008, Liebst and Schneller 2008, Liza et al. 2010, Rahman et al. 2012, Ferdousi et al. 2014). However, no study has evaluated for germination of anticancerous plants in Bangladesh so far. Therefore, the aim of the present study is to investigate seed germination behaviour of six commonly available anticancerous plants in Bangladesh including their dormancy, suitable period of germination, and rate and nature of germination, which might help in carrying these plants under cultivation.

\section{Materials and Methods}

Plant materials: Six anticancerous plants investigated in this study are listed with their families, vernacular names, habit, parts used and tested cancer lines in Table 1. The plants were selected because of their availability throughout the country and used by the local people in different parts of the country. Plant specimens were collected from different areas of Bangladesh and planted in the Botanical Garden of Dhaka University for 
observation and decisive study (Fig. 1). The voucher specimens are deposited in Dhaka University Salar Khan Herbarium (DUSH).

Seed collection and sowing: Seeds were collected from mature fruits before noon and stored in natural condition at normal temperature. Earthen tubs (12") were taken and filled with sandy loam soil and compost $(2: 1)$. Ten seeds of each species were sown to a depth of about $1 \mathrm{~cm}$ in the earthen tubs. The tubs were kept in semi-shaded places and watered regularly (Ferdousi et al. 2014). Ten seeds per tub were sown at different time interval of the year to record dormancy, suitable period of germination, percentage of germination and nature of germination.

Table 1. List of anticancerous plants employed in the study with their tested cancer cells.

\begin{tabular}{|c|c|c|c|c|c|c|}
\hline No. & Species & $\begin{array}{l}\text { Bangla } \\
\text { name }\end{array}$ & Habit & $\begin{array}{l}\text { Parts } \\
\text { used }\end{array}$ & $\begin{array}{l}\text { Tested cancer } \\
\text { cells }\end{array}$ & References \\
\hline 1. & $\begin{array}{l}\text { Boerhavia diffusa L. } \\
\text { (Family: Nyctaginaceae) }\end{array}$ & Punornova & Herb & $\begin{array}{l}\text { Whole } \\
\text { plant }\end{array}$ & $\begin{array}{l}\text { Cervical cancer } \\
(\mathrm{SiHa}) \text { cell line }\end{array}$ & Venkatajothi (2017) \\
\hline 2. & $\begin{array}{l}\text { Calotropis procera (Ait.) } \\
\text { R. Br. (Family: } \\
\text { Asclepiadaceae) }\end{array}$ & Akando & Shrub & Leaf & $\begin{array}{l}\text { Human } \\
\text { epidermal } \\
\text { carcinoma of the } \\
\text { nasopharynx }\end{array}$ & $\begin{array}{l}\text { van Valkenburg and } \\
\text { Bunyapraphatsara } \\
(2002)\end{array}$ \\
\hline 3. & $\begin{array}{l}\text { Jatropha gossypifolia L. } \\
\text { (Family: Euphorbiaceae) }\end{array}$ & Laljeol & Shrub & Stem & Jatrophone & Evans (2009) \\
\hline 4. & $\begin{array}{l}\text { Leonurus sibiricus L. } \\
\text { (Family: Lamiaceae) }\end{array}$ & Roktodron & Herb & Stem & $\begin{array}{l}\text { Pregnancy- } \\
\text { dependent } \\
\text { mammary tumours }\end{array}$ & $\begin{array}{l}\text { Nagasawa et al. } \\
(1990)\end{array}$ \\
\hline 5. & $\begin{array}{l}\text { Plumbago zeylanica L. } \\
\text { (Family: Plumbaginaceae) }\end{array}$ & Chita & Shrub & Root & $\begin{array}{l}\text { Dalton's ascitic } \\
\text { lymphoma }\end{array}$ & $\begin{array}{l}\text { Kavimani et al. } \\
\text { (1996) }\end{array}$ \\
\hline 6. & $\begin{array}{l}\text { Ricinus communis L. } \\
\text { (Family: Euphorbiaceae) }\end{array}$ & Rerhi & Shrub & Seed & $\begin{array}{l}\text { Colon cancer cell } \\
\text { lines }\end{array}$ & Padala (2014) \\
\hline
\end{tabular}

\section{Results and Discussion}

The present study revealed that seeds of all six anticancerous plants employed in the study germinated. Results of seed germination in the tested plant species are presented in Table 2. In Boerhavia diffusa, seeds sown immediately after collection in December took about 100 days to germinate, whereas seeds sown in March took 70 days, and sown in June took 90 days and again in December of the next year also took about 90 days to germinate. The rate of germination was found $60-70 \%$ at different time intervals throughout the year. Seeds remained viable up to one year of collection. All B. diffusa seedlings survived. 

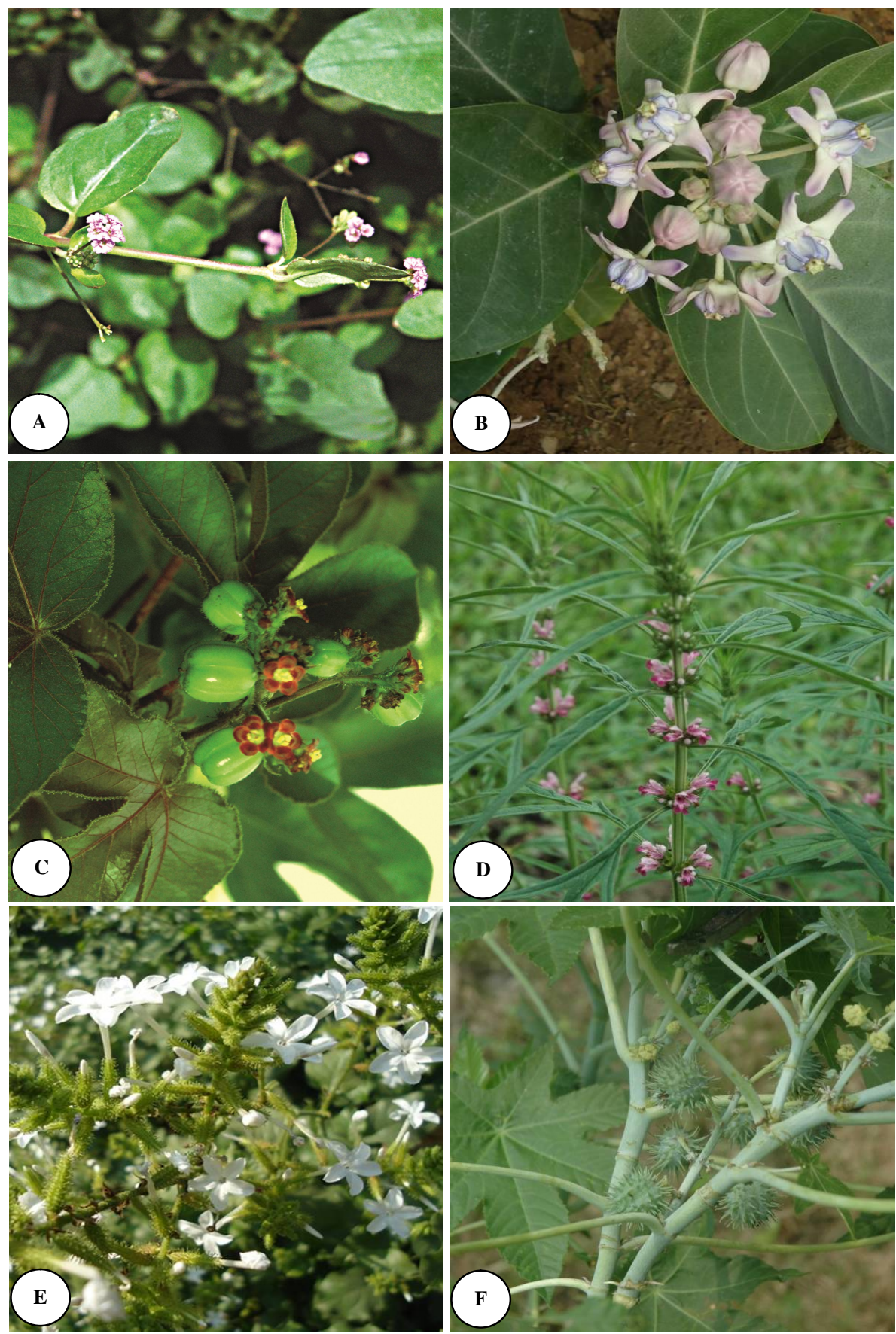

Fig. 1. Six anticancerous plants of Bangladesh. A. Boerhavia diffusa; B. Calotropis procera; C. Jatropha gossypifolia; D. Leonurus sibiricus; E. Plumbago zeylanica and F. Ricinus communis. 
Seeds of Calotropis procera germinated after 9 days of sowing in June and the rate of germination was $80 \%$, whereas it took 15 days to germinate when sown in September, and the percentage of germination was found to be 40 which indicated loss of viability possibly started in September (Table 2). The suitable period for germination was in the month of June. Seeds when sown in December and then in next April, did not germinate indicating loss of viability at that time. The rate of survival of seedlings was $100 \%$ in $C$. procera.

Table 2. Results of seed germination of six anticancerous species.

\begin{tabular}{|c|c|c|c|c|c|c|}
\hline Species & $\begin{array}{c}\text { Date of } \\
\text { seed } \\
\text { collection } \\
\end{array}$ & $\begin{array}{c}\text { Date of seed } \\
\text { sowing }\end{array}$ & $\begin{array}{c}\text { No. of } \\
\text { seeds } \\
\text { sown }\end{array}$ & $\begin{array}{c}\text { No. of } \\
\text { seeds } \\
\text { germinated }\end{array}$ & $\begin{array}{c}\text { Days } \\
\text { taken to } \\
\text { germinate } \\
\end{array}$ & $\begin{array}{c}\% \text { of } \\
\text { germination }\end{array}$ \\
\hline \multirow[t]{4}{*}{ Boerhavia diffusa L. } & \multirow[t]{4}{*}{17.12 .2012} & 27.12.2012 & 10 & 7 & 100 & 70 \\
\hline & & 27.03 .2013 & 10 & 7 & 70 & 70 \\
\hline & & 27.06 .2013 & 10 & 6 & 90 & 60 \\
\hline & & 20.12 .2013 & 10 & 7 & 90 & 70 \\
\hline \multirow{4}{*}{$\begin{array}{l}\text { Calotropis procera } \\
\text { (Ait.) R. Br. }\end{array}$} & \multirow[t]{4}{*}{02.06 .2012} & 09.06 .2012 & 10 & 8 & 9 & 80 \\
\hline & & 22.09 .2012 & 10 & 4 & 15 & 40 \\
\hline & & 27.12 .2012 & 10 & - & - & - \\
\hline & & 27.04 .2013 & 10 & - & - & - \\
\hline \multirow[t]{4}{*}{ Jatropha gossypifolia L. } & \multirow[t]{4}{*}{26.05 .2012} & 27.05 .2012 & 10 & 8 & 120 & 80 \\
\hline & & 22.09 .2012 & 10 & 3 & 24 & 30 \\
\hline & & 27.12 .2012 & 10 & - & - & - \\
\hline & & 27.04 .2013 & 10 & - & - & - \\
\hline \multirow[t]{4}{*}{ Leonurus sibiricus L. } & \multirow[t]{4}{*}{28.04 .2012} & 28.04 .2012 & 10 & 4 & 130 & 40 \\
\hline & & 29.07 .2012 & 10 & 2 & 75 & 20 \\
\hline & & 22.11 .2012 & 10 & - & - & - \\
\hline & & 27.03 .2013 & 10 & - & - & - \\
\hline \multirow[t]{4}{*}{ Plumbago zeylanica L. } & \multirow[t]{4}{*}{10.02 .2012} & 10.02 .2012 & 10 & 8 & 34 & 80 \\
\hline & & 26.05 .2012 & 10 & 10 & 11 & 100 \\
\hline & & 22.08 .2012 & 10 & - & - & - \\
\hline & & 22.12 .2012 & 10 & - & - & - \\
\hline \multirow[t]{4}{*}{ Ricinus communis L. } & \multirow[t]{4}{*}{23.03 .2012} & 28.03.2012 & 10 & 1 & 120 & 10 \\
\hline & & 30.06 .2012 & 10 & 4 & 14 & 40 \\
\hline & & 22.09 .2012 & 10 & 3 & 15 & 30 \\
\hline & & 22.01.2013 & 10 & - & - & - \\
\hline
\end{tabular}

In Jatropha gossypifolia, seeds sown immediately after collection in May took a very long time, i.e. 120 days to germinate, but when seeds were sown in September after three months of seed collection it took comparatively very less time, only 24 days to germinate. There was at least three months of dormancy period for this species. The rate of germination was highest (80\%) when sown in May and only 30\% when sown in September. Dropping of seed viability started after four months of seed collection. No seed of $J$. gossypifolia sown in December and April of next year germinated as seeds lost their viability. All seedlings of J. gossypifolia survived. 
In the case of Leonurus sibiricus, seeds germinated after 130 days of sowing in April and the rate of germination was $40 \%$. Seeds sown in July took 75 days to germinate with $20 \%$ germination rate. The study indicated that there was at least three to four months of dormancy period. Seeds did not germinate when they were sown in November and next March. Viability of seeds lost after four months of collection. The seedlings' survival rate was found to be $100 \%$.

Plumbago zeylanica seeds germinated after 11 days of sowing. Seeds sown immediately after collection in February took 34 days to germinate, however, it took 11 days to germinate when they were sown in May. There was at least one month of dormancy period. The percentage of germination was found highest (100) in May which indicated the most suitable period for germination. No seed germinated when sown in August and December. Viability started losing after three months of seed collection. Cent per cent of its seedlings survived.

Seeds of Ricinus communis required 120 days for their germination when they were sown immediately after collection in March. Days taken for germination were 14 and 15 when seeds were sown in June and September, respectively. There was at least four months of dormancy period and loss of viability started after six months of seed collection. The rate of germination was found to be 10,40 and 30\% when sown in March, June and September, respectively. Seeds sown in January did not germinate as they lost viability in this period. All seedlings of $R$. communis survived. Among all the species investigated the minimum time required for seed germination was observed in Calotropis procera ( 9 days). In contrast, the maximum time (130 days) needed for germination was found in Leonurus sibiricus (Tables 2 and 3).

Table 3. Comparative data on seed germination of six anticancerous plants of Bangladesh.

\begin{tabular}{llccc}
\hline \multicolumn{1}{c}{ Species } & $\begin{array}{l}\text { Optimum } \\
\text { period of seed } \\
\text { germination }\end{array}$ & $\begin{array}{c}\text { Minimum days } \\
\text { taken for } \\
\text { germination }\end{array}$ & $\begin{array}{c}\% \text { of } \\
\text { germination }\end{array}$ & $\begin{array}{c}\text { Type of } \\
\text { germination }\end{array}$ \\
\hline Boerhavia diffusa L. & March - June & 70 & $60-70$ & Epigeal \\
Calotropis procera (Ait.) R. Br. & June & 9 & $40-80$ & $"$ \\
Jatropha gossypifolia L. & September & 24 & $30-80$ & $"$ \\
Leonurus sibiricus L & August & 75 & $20-40$ & $"$ \\
Plumbago zeylanica L. & June & 11 & $80-100$ & $"$ \\
Ricinus communis L. & July & 14 & $10-40$ & $"$ \\
\hline
\end{tabular}

A comparative account on optimum period for seed germination, minimum days taken for germination, and percentage of germination among six anticancerous plants investigated is summarized in Table 3. The minimum days taken for seed germination in B. diffusa, $C$. procera, J. gossypifolia, L. sibiricus, $P$. zeylanica and $R$. communis are 70, 9, 24, 75, 11 
and 14, respectively. The nature of seed germination in all the species was found to be epigeal (Table 3).

The present study demonstrated that seeds germinated in all the six anticancerous species and the germination rate varied from 10 to $100 \%$. The highest germination rate was observed in Plumbago zeylanica followed by Calotropis procera and Jatropha gossypifolia. In contrast, the lowest rate of seed germination was noticed in Ricinus communis (Table 3). Ghosh and Maiti (2014) stated that some factors broke the dormancy of seeds and increased the percentage of germination when seeds were applied separately to mechanical and acid scarification. The rate of seed germination could be enhanced by pre-sowing treatments. Abera et al. (2008) reported 9 days for germination of seeds in Plumbago zeylanica after seed sowing. The present study revealed that Plumbago zeylanica seeds took 11 days to germinate and the germination rate was very high (80 $100 \%$ ), which was in conformity with Abera et al. (2008). Galal et al. (2015) investigated the effect of temperature, salinity and light in Calotropis procera and concluded that the highest seed germination $(98.7 \%$ ) was found in dark condition, while no germination occurred in light condition. In this study, seed germination rate varied from $40-80 \%$ in Calotropis procera and the low rate of germination might be because of semi-shaded condition, immature nature of seeds and sowing period. Seeds of Calotropis procera, Jatropha gossypifolia, Leonurus sibiricus, Plumbago zeylanica and Ricinus communis lost their viability after certain period, and Boerhavia diffusa, Jatropha gossypifolia, Leonurus sibiricus and Ricinus communis exhibited different dormancy periods. Several environmental factors, such as light intensity, temperature, water availability, and soil salinity influenced seed germination phenomena and seedling emergence (Baskin and Baskin 1988). In order to break dormancy certain environmental conditions should be taken into consideration, and after breaking dormancy other conditions are also needed to allow seed germination and seedling development (Bewley 1997).

\section{References}

Abera, B., L. Negash and J. Kumlehn. 2008. Reproductive biology in the medicinal plant, Plumbago zeylanica L. African J. Biotechnol. 7: 3447-3454.

Ahmed, Z.U., M.A. Hassan, Z.N.T. Begum, M. Khondker, S.M.H. Kabir, M. Ahmad, A.T.A. Ahmed, A.K.A. Rahman and E.U. Haque. (eds) 2008. Encyclopedia of Flora and Fauna of Bangladesh, Vol. 7. Angiosperms: Dicotyledons (Balsaminaceae - Euphorbiaceae). Asiatic Society of Bangladesh, Dhaka. 546 pp.

Baskin, C.C., P.L. Chesson and J.M. Baskin. 1993. Annual seed dormancy cycles in two desert winter annuals. J. Ecol. 81: 551-556.

Baskin, J.M. and C.C. Baskin. 1988. Germination ecophysiology of herbaceous plant species in a temperate region. Amer. J. Bot. 75: 286-305.

Bewley, J.D. 1997. Seed germination and dormancy. Plant Cell 9: 1055-1066. 
Chauhan, B.S. and D.E. Johnson. 2008. Influence of environmental factors on seed germination and seedling emergence of Eclipta (Eclipta prostrata) in a tropical environment. Weed Sci. 56: 383388.

Evans, W.C. 2009. Trease and Evans' Pharmacognosy. W.B. Saunders. 416-427 pp.

Ferdousi, A., M.O. Rahman and M.A. Hassan. 2014. Seed germination behavior of six medicinal plants from Bangladesh. Bangladesh J. Plant Taxon. 21(1): 71-76.

Galal, T.M., E.A. Farahat, M.M. El-Midany and L.M. Hassan. 2015. Effect of temperature, salinity, light and time of dehiscence on seed germination and seedling morphology of Calotropis procera from urban habitats. African J. Biotechnol. 14: 1275-1282.

Ghani, A. 2003. Medicinal Plants of Bangladesh (Second edition). Asiatic Society of Bangladesh, Dhaka, Bangladesh. 603 pp.

Ghosh, P.K. and T.K. Maiti. 2014. Effect of seed scarification on in vitro seed germination of Abrus precatorius L. Plant Archiv. 14(2): 881-885.

Greenwell, M. and P.K.S.M. Rahman. 2015. Medicinal Plants: Their use in anticancer treatment. Int. J. Pharm. Sci. Res. 6(10): 4103-4112.

Hassan, M.A. and Z. Fardous. 2003. Seed germination, pollination and phenology of Gloriosa superba L. (Liliaceae). Bangladesh J. Plant Taxon. 10(1): 95-97.

Hartwell, J.L. 1982. Plants used against cancer. A survey, USA7 Quarterman Publications, Lawrence, MA. 438-439 pp.

Kavimani, S., R. Ilango, M. Madheswaran, B Tayakar, M. Gupta and U.K. Majumdar. 1996. Antitumour activity of Plumbagin against Dalton's ascetic lymphoma. Ind. J. Pharm. Sci. 58(5): 194-196.

Liebst, B. and J.S. Schneller. 2008. Seed dormancy and germination behavior in two Euphrasia species (Orobanchaceae) occurring in the Swiss Alps. Bot. J. Linn. Soc. 156: 649-656.

Liza, S.A., M.O. Rahman, M.Z. Uddin, M.A. Hassan and M. Begum. 2010. Reproductive biology of three medicinal plants. Bangladesh J. Plant Taxon. 17(1): 69-78.

Nagasawa, H., T. Onoyama, M. Suzuki, A. Hibino, T. Segawa and H. Inatomi. 1990. Effects of motherwort (Leonurus sibiricus L.) on preneoplastic and neoplastic mammary gland growth in multiparous GR/A mice. Anticancer Res. 10: 1019-1024.

Nunez, D.R. and O.C. de Castro. 1992. The ethnobotany of Labiatae of the Old World. In: Harley, R.M. and T. Reynolds. (eds) Advances in Labiatae Science, Royal Botanic Gardens, Kew. 455$473 \mathrm{pp}$.

Padala, V.S.P. 2014. Extraction, purification and analysis of anticancer activity of Ricin on colon cancer cell lines and testing its efficacy using Insilco Docking. Helix 6: 613-616.

Rahman, M.Z., M.O. Rahman and M.A. Hassan. 2012. Seed germination of two medicinal plants: Desmodium pulchellum (L.) Benth. and D. triflorum (L.) DC. Bangladesh J. Plant Taxon. 19(2): 209-212.

Rastogi, R.P. and B.N. Mehrotra. 1993. Compendium of Indian Medicinal Plants, Vol. 2. Central Drug Research Institute, Lucknow and Publication \& Information Directorate, New Delhi, India.

Sadhu, M.K. 1989. Plant Propagation (Reprint 1999). New Age International (P) Limited, Publishers, New Delhi. 57 p.

Singh, V.K. and Z.A. Ali. 1998. Herbal Drugs of Himalaya. Today and Tomorrow's Printer and Publishers, New Delhi, India. 156 pp. 
Sultana, N. 2017. Taxonomy, propagation and chemical properties of some selected anticancerous plants of Bangladesh. Ph.D. Thesis submitted to the University of Dhaka, Bangladesh (unpublished).

van Valkenburg, J.L.C.H. and N. Bunyapraphatsara. (eds) 2002. Plant Resources of South-East Asia, No. 12(2). Medicinal and Poisonous Plants 2. Prosea foundation, Bogor, Indonesia. 782 pp.

Venkatajothi, R. 2017. In-viro anticancer activity of Boerhaavia diffusa Linn. Int. J. Curr. Res. Biol. Med. 2(3): 20-24.

Yusuf, M., J.U. Chowdhury, M.N. Haque and J. Begum. 2009. Medicinal Plants of Bangladesh. Bangladesh Council of Scientific and Industrial Research, Chittagong, Bangladesh.

(Revised copy received on 16.05.2019) 